\title{
Impact assessment of some heavy metals on tilapia fish, Oreochromis niloticus, in Burullus Lake, Egypt
}

\author{
Omnya A. El-Batrawy ${ }^{1 *}$, Maie I. El-Gammal ${ }^{1}$, Lamiaa I. Mohamadein² ${ }^{2}$ Dina H. Darwish² and Khalid M. El-Moselhy ${ }^{2}$
}

\begin{abstract}
Background: Burullus Lake has received a great attention because of its environmental and economic importance for being a significant source of fish production in Egypt. It is subjected to many of environmental changes due to the huge amount of discharges originated from different sources as well as many human activities. The Nile tilapia (Oreochromis niloticus) is an abundant sedentary fish present in the most Egyptian lakes, Nile River, and ponds. The study was designed to evaluate some metal pollution in Burullus Lake.

Results: The values of heavy metals ( $\mathrm{Mn}, \mathrm{Zn}, \mathrm{Fe}, \mathrm{Ni}, \mathrm{Cu}$, and $\mathrm{Pb}$ ) were measured in lake water and muscles of $\mathrm{O}$. niloticus fish during winter and summer 2014. Water samples were collected from six sampling sites, while fish samples were collected from the three sectors (eastern, middle, and western) of the lake. The mean values of heavy metals (Mn, Zn, Fe, Ni, Cu, and Pb) in surface water of Burullus Lake during winter and summer for the year 2014 were $1.09,10.50,29.38,6.87,2.05$, and $5.98 \mu \mathrm{g} / \mathrm{L}$, respectively, whereas the annual means of heavy metals ( $\mathrm{Mn}, \mathrm{Zn}$, $\mathrm{Fe}, \mathrm{Ni}, \mathrm{Cu}$, and $\mathrm{Pb}$ ) in the muscles of $\mathrm{O}$. niloticus fish were $0.68,4.70,10.62,0.52,0.39$, and $0.46 \mu \mathrm{g} / \mathrm{g}$ wet wt., respectively.

Conclusions: In lake water, Mn was the lowest concentration of the six sampling sites, while Fe was the highest concentration, whereas in fish muscles, Cu recorded the lowest concentration of the three sectors, while Fe was the highest concentration. The southern part of Burullus Lake had the highest heavy metal values as it influenced by the discharge of massive amounts of domestic sewage as well as agricultural and industrial effluents. The accumulation of heavy metals in fish muscles of the three sectors showed different patterns. Generally, the values of metals in the fish muscles were accepted by the international legislation limits and are safe for human consumption.
\end{abstract}

Keywords: Burullus Lake, Metals, Water, Nile tilapia, Oreochromis niloticus

\section{Background}

Heavy metals have received considerable attention due to their toxicity, long-term persistence, bioaccumulation, and bio-magnification at various trophic levels (Ololade et al., 2008). Distribution of heavy metals in water, sediments, and organisms used to assess the contamination degree of the aquatic environment.

Fish are at a higher level of the food chain, and they are widely used to biologically monitor the degree of metal pollution in aquatic ecosystems (Al-SayeghPetkovšek et al., 2012), as fish may concentrate large amounts of some metals from the water (Daviglus et al., 2002). Toxic

\footnotetext{
*Correspondence: om_elbatrawy@du.edu.eg; om_elbatrawy@hotmail.com ${ }^{1}$ Department of Environmental Sciences, Faculty of Science, Damietta University, New Damietta City, Damietta 34517, Egypt

Full list of author information is available at the end of the article
}

elemental contaminants are transferred into human metabolism through consumption of contaminated fish that leads to serious deterioration of human health status (Alinnor and Obiji, 2010). Therefore, they are highly toxic for consumers when exceeding the recommended safety concentrations (Basiony, 2014).

The contamination of water bodies in the Egyptian Nile Delta by metals is caused by the discharge of massive amounts of domestic sewage as well as agricultural and industrial effluents (Alne-na-ei, 2003). The Nile tilapia (Oreochromis niloticus) is an abundant sedentary fish present in the most Egyptian lakes, Nile River, and ponds. In addition, it is used as bio-indicator species in understanding environmental pollution (Firat and Kargin, 2010).

Burullus Lake is the second largest coastal lake in Egypt. It has received a great attention because of its 
environmental and economic importance for being a significant source of fish production in Egypt. It is suffering from changes in water quality that resulted from the high load of effluents discharged directly into it (Darwish, 2011).

The study was designed to evaluate some metal pollution in Burullus Lake. The values of heavy metals $(\mathrm{Mn}$, $\mathrm{Zn}, \mathrm{Fe}, \mathrm{Ni}, \mathrm{Cu}$, and $\mathrm{Pb}$ ) were measured in lake water and muscles of fish (Oreochromis niloticus) during winter and summer 2014. Therefore, this will provide effective monitoring of both environmental quality and the health of the organisms that inhabiting the lake ecosystem.

\section{Methods}

\section{Study area}

Burullus Lake is situated in a middle locus between the two branches of the Nile that forms the Delta. It extends between $30^{\circ} 22^{\prime}-31^{\circ} 35^{\prime} \mathrm{N}$ and $30^{\circ} 33^{\prime}-31^{\circ} 08^{\prime} \mathrm{E}$. It connects to the sea through a narrow strait called Al-burg inlet or Boughaz El-Burullus at its northeast side. The lake is separated from the sea by a narrow coastal strip covered by sand sheets and sand dunes. It receives about 4.1 billion $\mathrm{m}^{3}$ drainage water annually through a system of eight drains, namely, West El-Burullus, Gharbia Drain, ElKhashaah Drain, Tirrah Drain, Drain No. 7, Drain No. 8, Drain No. 9, El-Hoks Drain, and Brinbal Freshwater Canal (EMI, 2012). Agricultural lands encompass the southern and eastern fringes of the lake (Fig. 1).

\section{Sampling protocol}

Surface water samples were collected during winter and summer for the year 2014 from six sampling sites, two samples of each, distributed over Burullus Lake (Table 1).
The samples were collected $20 \mathrm{~cm}$ below the water surface by dipping the acid-washed polyethylene bottle into the lake from a row boat. Collected water samples were transferred to the lab for heavy metal determination keeping in ice box.

Fish samples (5-8 specimens with a length of about 15 $\pm 2 \mathrm{~cm}$ ) were collected from the three sectors (eastern, middle, and western) of the lake. Nile tilapia (Oreochromis niloticus) was collected fresh from the local fishermen during the same period of water sampling. After transferring to the lab, fish were dissected freshly to obtain the muscles and then frozen until analysis.

Determination of heavy metals in water and fish samples Water samples were filtered using $0.45-\mu \mathrm{m}$ membrane filters (APHA, 1999). The filtrate water samples were preconcentrated individually with APDC (ammonium pyrrolidine di-thiocarbamate)-MIBK (methyl isobutyl ketone) extraction procedure. In fish samples, muscles were taken separately from each individual, weighted, and analyzed according to Schuhmacher and Domingo (1996).The values of $\mathrm{Mn}, \mathrm{Zn}, \mathrm{Fe}, \mathrm{Cu}, \mathrm{Ni}$, and $\mathrm{Pb}$ were measured using flame atomic absorption spectrophotometer (AAS; PerkinElmer Analyst 100). The results of water samples were expressed as $\mu \mathrm{g} / \mathrm{L}$ while the results of fish samples were expressed as $\mu \mathrm{g} / \mathrm{g}$ wet wt.

\section{Bioconcentration factor (BCF) estimations}

Bioconcentration is a situation in which the levels of a pollutant in an organism exceed the levels of that in the surrounding environment. Bioconcentration factors (BCFs) are defined as the ratio of the steady-state metal ion

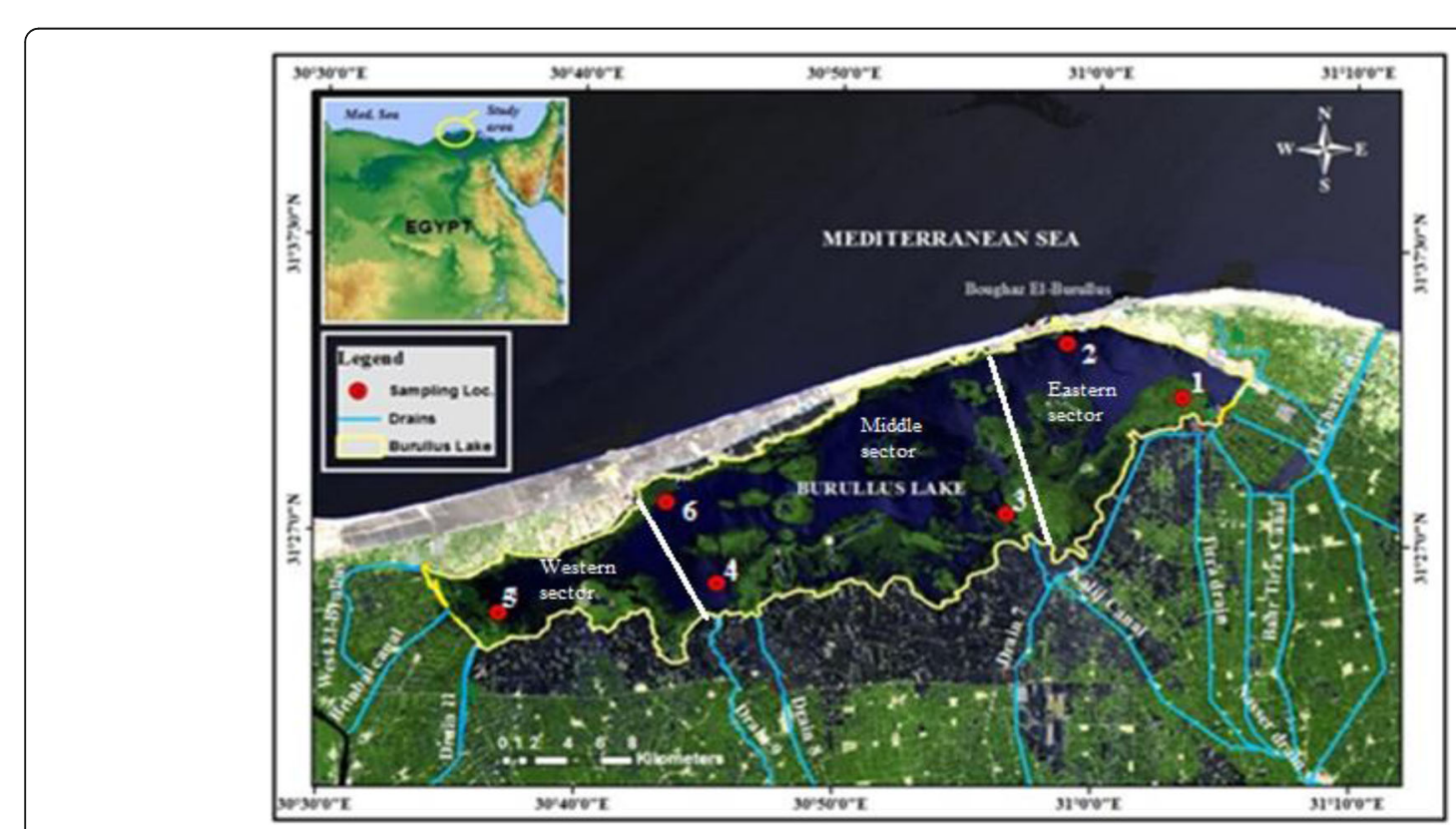

Fig. 1 Map of Burullus Lake showing the sampling sites 
Table 1 The description of sampling sites in Burullus Lake

\begin{tabular}{|c|c|c|}
\hline Site no. & Site name & Description \\
\hline 1 & Burullus East & $\begin{array}{l}\text { It is located in the eastern area of the lake which receives the drainage water from Khashaa (El-Gharbia) main drain, Terra } \\
\text { drain, and Burullus East drain. }\end{array}$ \\
\hline 2 & Boughaz & It is located in the front of Boughaz El-Burullus (outlet). \\
\hline 3 & Drain No. 7 & It is located in the front of Drain No. 7 \\
\hline 4 & Shakhloba & It is located in the front of Drain No. 9 and receives drainage water from drains Nos. 8 and 9. \\
\hline 5 & Hoksa & $\begin{array}{l}\text { It is located in the western area of the lake and receives drainage water from drain No. 11, Burullus west drain, and fresh } \\
\text { water from Brinbal Canal. }\end{array}$ \\
\hline 6 & Mastroh & It is located in the northern area of the lake. \\
\hline
\end{tabular}

concentrations in the fish tissue vs the concentration in water/sediments (Orata and Birgen, 2016). The higher the ratio, the more severe the bioconcentration of pollutants, in this study, the heavy metal level in fish. The BCFs were calculated using the following equation (Gobas et al., 2009);

$$
\mathrm{BCF}=\frac{\text { Concentration in fish at steady state }(\mathrm{mg} / \mathrm{kg} \text { wet fish })}{\text { Concentration in water at steady state }(\mathrm{mg} / \mathrm{L})}
$$

\section{Heavy metal indices for pollution assessment}

The degree of metal contamination could be evaluated by the determination of the contamination factor (CF), pollution load index (PLI), and metal pollution index (MPI) from the following formulae (Tomlinson et al., 1980 and Usero et al., 2005):

$$
\mathrm{CF}=C_{\text {metal }} / C_{\text {background }}
$$

where $C_{\text {metal }}$ is the metal concentration and $C_{\text {background }}$ is the background concentration of each metal. In the present study, the lowest mean concentration was used as baseline/ or background values. Contamination factor (CF) referred that $\mathrm{CF}<1$ refers to low contamination, $1 \geq \mathrm{CF}<3$ means moderate contamination, $3 \geq \mathrm{CF} \geq 6$ indicates considerable contamination, and CF $>6$ indicates very high contamination (Harikumar and Jisha 2010).

$$
\mathrm{PLI}=\left(\mathrm{CF}_{1} \times \mathrm{CF}_{2} \times \mathrm{CF}_{3} \times \cdots \times \mathrm{CF}_{n}\right)^{1 / n}
$$

where $n$ is the number of metals and CF is the contamination factor. When the value of PLI is $<1$, a low of pollution is suggested. The PLI value of one indicates the presence of only baseline level of pollutants while value above one indicates progressive deterioration of the site and estuarine quality (Tomlinson et al., 1980).

$$
\mathrm{MPI}=\left(M_{1} \times M_{2} \times M_{3} \times \cdots \cdots \times M_{n}\right)^{1 / n}
$$

where $n$ and $M$ are the metal number and metal concentration, respectively.

\section{Statistical analyses}

The comparison between means and standard deviations was tested for significance $(P \leq 0.05)$ using ANOVA analysis, Duncan's multiple range test, and $t$ test. In addition, the relationship among heavy metals in water was assessed using Pearson's correlation coefficient. All statistical analyses were done using the computer program of SPSS Inc. (2007, version 16.0 for Windows XP).

\section{Results}

Evaluation of heavy metals ( $\mathrm{Mn}, \mathrm{Zn}, \mathrm{Fe}, \mathrm{Ni}, \mathrm{Cu}$, and $\mathrm{Pb}$ ) in Burullus Lake

Table 2 represents the average values of heavy metals ( $\mathrm{Mn}, \mathrm{Zn}, \mathrm{Fe}, \mathrm{Ni}, \mathrm{Cu}$, and $\mathrm{Pb}$ ) in surface water of Burullus Lake during winter and summer seasons for the year 2014. The descriptive statistics of heavy metal values are presented in Table 3.The annual means of $\mathrm{Mn}, \mathrm{Zn}, \mathrm{Fe}$, $\mathrm{Ni}, \mathrm{Cu}$, and $\mathrm{Pb}$ were $1.09,10.50,29.38,6.87,2.05$, and $5.98 \mu \mathrm{g} / \mathrm{L}$, respectively. The order of heavy metals in the water of Burullus Lake was $\mathrm{Fe}>\mathrm{Zn}>\mathrm{Ni}>\mathrm{Pb}>\mathrm{Cu}>\mathrm{Mn}$.

The concentration of $\mathrm{Mn}$ in lake water was nondetected at Boughaz (site 2) during summer. The highest value of $\mathrm{Mn}$ in Burullus Lake water was $2.58 \mu \mathrm{g} / \mathrm{L}$ at the front of Hoksa (site 5) during winter whereas the lowest concentration of $\mathrm{Mn}$ was $0.1 \mu \mathrm{g} / \mathrm{L}$ during summer at both the front of Hoksa and Mastroh (sites 5 and 6). Levels of zinc, Zn, in Burullus Lake water ranged from $2.68 \mu \mathrm{g} / \mathrm{L}$ during summer at the front of Hoksa site to $44.44 \mu \mathrm{g} / \mathrm{L}$ during winter at site front of Drain No.7. The highest value of iron, Fe, in Burullus Lake water was $92.54 \mu \mathrm{g} / \mathrm{L}$ during summer at Burullus East (site 1), whereas the lowest concentration of $\mathrm{Fe}$ in lake water was $7.66 \mu \mathrm{g} / \mathrm{L}$ during winter at Mastroh (site 6).

The highest value of nickel, $\mathrm{Ni}$, in lake water was 11.64 $\mu \mathrm{g} / \mathrm{L}$ during summer at Mastroh (site 6), whereas the lowest concentration of $\mathrm{Ni}$ in lake water was $2.94 \mu \mathrm{g} / \mathrm{L}$ during winter at the front of Hoksa (site5). The highest value of copper, $\mathrm{Cu}$, in Burullus Lake water was $3.36 \mu \mathrm{g} / \mathrm{L}$ during summer at Mastroh (site 6), whereas the lowest concentration of $\mathrm{Cu}$ in lake water was $0.78 \mu \mathrm{g} / \mathrm{L}$ during winter at the front of Hoksa (site 
Table 2 Average values of heavy metals $(\mu \mathrm{g} / \mathrm{L})$ in surface water of Burullus Lake during winter and summer 2014

\begin{tabular}{|c|c|c|c|c|c|c|c|c|c|c|c|c|c|}
\hline \multirow[t]{2}{*}{ Site } & & \multicolumn{6}{|c|}{ Winter } & \multicolumn{6}{|c|}{ Summer } \\
\hline & & $\mathrm{Mn}$ & $\mathrm{Zn}$ & $\mathrm{Fe}$ & $\mathrm{Ni}$ & $\mathrm{Cu}$ & $\mathrm{Pb}$ & $\mathrm{Mn}$ & $\mathrm{Zn}$ & $\mathrm{Fe}$ & $\mathrm{Ni}$ & $\mathrm{Cu}$ & $\mathrm{Pb}$ \\
\hline 1 & Burullus East & 0.42 & 12.02 & 20.74 & 3.12 & 2.02 & 1.68 & 1.48 & 4.82 & 92.54 & 9.04 & 2.66 & 1.48 \\
\hline 2 & Boughaz & 0.80 & 11.96 & 10.38 & 3.72 & 1.06 & 3.40 & N.D. & 4.06 & 19.62 & 8.60 & 2.42 & 12.50 \\
\hline 3 & Front of Drain No.7 & 1.84 & 44.44 & 10.56 & 3.28 & 2.16 & N.D. & 1.74 & 3.74 & 23.66 & 10.08 & 2.12 & 9.08 \\
\hline 4 & Shakhloba & 0.36 & 9.40 & 20.04 & 4.10 & 1.12 & 0.32 & 2.34 & 5.82 & 63.30 & 10.88 & 3.16 & 7.08 \\
\hline 5 & Front of Hoksa & 2.58 & 12.44 & 14.94 & 2.94 & 0.78 & N.D. & 0.10 & 2.68 & 13.96 & 10.26 & 1.04 & 8.10 \\
\hline 6 & Mastroh & 0.18 & 11.74 & 7.66 & 4.80 & 2.72 & N.D. & 0.10 & 2.92 & 55.10 & 11.64 & 3.36 & 10.2 \\
\hline
\end{tabular}

N.D. not detected

5). Concentrations of lead $(\mathrm{Pb})$ in Burullus Lake water were non-detected at sites front of Drain No.7 (site 3), front of Hoksa (site 5), and Mastroh (site 6) during winter. The highest value of $\mathrm{Pb}$ in lake water was $12.50 \mu \mathrm{g} / \mathrm{L}$ during summer at Boughaz (site2), whereas the lowest concentration of $\mathrm{Pb}$ in Burullus Lake water was $0.32 \mu \mathrm{g} /$ L during winter at Shakhloba (site 4).

Table 4 and Fig. 2 present the annual mean of heavy metal concentrations, viz. $\mathrm{Mn}, \mathrm{Zn}, \mathrm{Fe}, \mathrm{Ni}, \mathrm{Cu}$, and $\mathrm{Pb}$, in Burullus Lake water during 2014. Generally, Mn and Zn recorded their highest values in lake water samples collected from the front of Drain No. 7 site. Fe recorded its highest value in lake water samples collected from Burullus East site, while $\mathrm{Ni}, \mathrm{Cu}$, and $\mathrm{Pb}$ showed their maximum concentrations at Mastroh site.

\section{Evaluation of heavy metals ( $\mathrm{Mn}, \mathrm{Zn}, \mathrm{Fe}, \mathrm{Ni}, \mathrm{Cu}$, and $\mathrm{Pb}$ ) for fish samples}

Table 5 represents the values of heavy metal (Mn, $\mathrm{Zn}$, $\mathrm{Fe}, \mathrm{Ni}, \mathrm{Cu}$, and $\mathrm{Pb}$ ) values ( $\mu \mathrm{g} / \mathrm{g}$ wet weight) in the muscles of $O$. niloticus fish collected from Burullus Lake during winter and summer for the year 2014. Table 6 represents the descriptive statistics of heavy metal values in the fish muscles. The annual means of heavy metals $\mathrm{Mn}, \mathrm{Zn}, \mathrm{Fe}, \mathrm{Ni}, \mathrm{Cu}$, and $\mathrm{Pb}$ in the muscles of $\mathrm{O}$. niloticus fish were $0.68,4.70,10.62,0.52,0.39$, and $0.46 \mu \mathrm{g} / \mathrm{g}$ wet wt., respectively. The order of heavy metals in the muscles of O. niloticus fish of Burullus Lake was $\mathrm{Fe}>\mathrm{Zn}>$ $\mathrm{Mn}>\mathrm{Ni}>\mathrm{Pb}>\mathrm{Cu}$.

The highest concentration of $\mathrm{Mn}$ in fish muscles was $1.34 \mu \mathrm{g} / \mathrm{g}$ wet wt. during winter at eastern sector, whereas the lowest concentration of $\mathrm{Mn}$ in fish muscles was $0.21 \mu \mathrm{g} / \mathrm{g}$ wet wt. during summer at western sector. The highest value of $\mathrm{Zn}$ in fish muscles was $6.23 \mu \mathrm{g} / \mathrm{g}$ wet wt. during summer at western sector, whereas the lowest concentration of $\mathrm{Zn}$ in fish muscles was $3.64 \mu \mathrm{g} / \mathrm{g}$ wet wt. during summer at eastern sector. The highest value of Fe in fish muscles was $17.66 \mu \mathrm{g} / \mathrm{g}$ wet wt. during winter at middle sector, whereas the lowest value of Fe in fish muscles was $6.39 \mu \mathrm{g} / \mathrm{g}$ wet wt. during summer western sector.

The highest value of $\mathrm{Ni}$ in fish muscles was $0.64 \mu \mathrm{g} / \mathrm{g}$ wet wt. during summer at eastern sector, whereas the lowest concentration of $\mathrm{Ni}$ in fish muscles was $0.43 \mu \mathrm{g} / \mathrm{g}$ wet wt. during winter at middle sector. The highest value of $\mathrm{Cu}$ in fish muscles was $0.53 \mu \mathrm{g} / \mathrm{g}$ wet wt. during winter at middle sector, whereas the lowest concentration of $\mathrm{Cu}$ in fish muscles was $0.28 \mu \mathrm{g} / \mathrm{g}$ wet wt. during summer at western sector. There was a significant difference $(p=0.021)$ for the annual mean of $\mathrm{Cu}$ concentration in muscles between the different sectors (eastern, middle, and western). The highest value of $\mathrm{Pb}$ in fish muscles was $0.81 \mu \mathrm{g} / \mathrm{g}$ wet wt. during winter at western sector, whereas the lowest concentration of $\mathrm{Pb}$ in fish muscles was $0.21 \mu \mathrm{g} / \mathrm{g}$ wet wt. during winter at eastern sector (Table 5).

Table 7 and Fig. 3 present the annual mean of heavy metals $(\mu \mathrm{g} / \mathrm{g}$ wet wt.) in O. niloticus muscles at each sector (eastern, middle, and western) of Burullus Lake during 2014. Generally, Mn and Ni recorded their highest values in fish muscles from the eastern sector; $\mathrm{Zn}$ and $\mathrm{Pb}$ were found in the western sector, while the maximum values of $\mathrm{Fe}$ and $\mathrm{Cu}$ were at middle sector. The highest annual mean value of $\mathrm{Mn}$ was $0.84 \mu \mathrm{g} / \mathrm{g}$ wet wt. recorded at the eastern sector which exhibited insignificant variation $(p=0.348)$ with the other sectors, where the lowest value $(0.49 \mu \mathrm{g} / \mathrm{g}$ wet wt.) was recorded at the middle sector. The obtained data revealed that

Table 3 Descriptive statistics of heavy metal values $(\mu \mathrm{g} / \mathrm{L})$ in the surface water of Burullus Lake during 2014

\begin{tabular}{lllllll}
\hline Metal & Mn & $\mathrm{Zn}$ & $\mathrm{Fe}$ & $\mathrm{Ni}$ & $\mathrm{Cu}$ & $\mathrm{Pb}$ \\
\hline Max & 2.58 & 44.44 & 92.54 & 11.64 & 3.36 & 12.5 \\
Min & 0.10 & 2.68 & 7.66 & 2.94 & 0.78 & $\mathrm{~N} . \mathrm{D}$. \\
Annual mean \pm SD & $1.09 \pm 0.94$ & $10.50 \pm 11.37$ & $29.38 \pm 26.50$ & $6.87 \pm 3.47$ & $2.05 \pm 0.87$ & $5.98 \pm 4.37$ \\
$p$ value & 0.842 & 0.041 & 0.038 & $<0.0001$ & 0.108 & 0.030 \\
\hline
\end{tabular}


Table 4 Annual mean of heavy metal concentration $(\mu \mathrm{g} / \mathrm{L})$ in Burullus Lake water during 2014

\begin{tabular}{lllllll}
\hline Site & $\mathrm{Mn}$ & $\mathrm{Zn}$ & $\mathrm{Fe}$ & $\mathrm{Ni}$ & $\mathrm{Cu}$ & $\mathrm{Pb}$ \\
\hline Burullus East & 0.95 & 8.42 & 56.64 & 6.08 & 2.34 & 1.58 \\
Boughaz & 0.8 & 8.01 & 15 & 6.16 & 1.74 & 7.95 \\
Front of Drain No. 7 & 1.79 & 24.09 & 17.11 & 6.68 & 2.14 & 9.08 \\
Shakhloba & 1.35 & 7.61 & 41.67 & 7.49 & 2.14 & 3.7 \\
Front of Hoksa & 1.34 & 7.56 & 14.45 & 6.6 & 0.91 & 8.1 \\
Mastroh & 0.14 & 7.33 & 31.38 & 8.22 & 3.04 & 10.2 \\
*PL $(\mu \mathrm{g} / \mathrm{L})$ & - & 5000 & 300.00 & 10 & 50.00 & 50.00
\end{tabular}

*PL (permissible limits) according to guidelines in EPA (2002)

there was no significant difference $(p=0.107)$ for the annual mean values of $\mathrm{Zn}$ in muscles at the three studied sectors, which ranged between 4.05 (eastern sector) and $5.79 \mu \mathrm{g} / \mathrm{g}$ wet wt. (western sector). The results showed that there were insignificant variations $(p=0.083)$ for the annual mean values of $\mathrm{Fe}$ in fish muscles, with means of $13.18,10.28$, and $8.42 \mu \mathrm{g} / \mathrm{g}$ wet wt. at the middle, eastern, and western sectors, respectively.

The obtained data revealed that the highest annual mean value of $\mathrm{Ni}(0.58 \mu \mathrm{g} / \mathrm{g}$ wet wt. $)$ in muscles was recorded at the eastern sector of Burullus Lake which exhibited a significant variation $(p=0.037)$ with the other sectors. The highest mean value $(0.47 \mu \mathrm{g} / \mathrm{g}$ wet wt.) was recorded in middle sector, whereas the lowest value $(0.32 \mu \mathrm{g} / \mathrm{g}$ wet wt.) was in western sector. The results recorded in Table 7 show that there were no significant differences $(p=0.095)$ for the annual mean values of $\mathrm{Pb}$ values in fish muscles from different sectors of Burullus Lake. The highest mean value $(0.57 \mu \mathrm{g} / \mathrm{g}$ wet wt.) was recorded at western sector, while the lowest one $(0.33 \mu \mathrm{g} / \mathrm{g}$ wet wt.) was at eastern sector.
Assessment of heavy metals ( $\mathrm{Mn}, \mathrm{Zn}, \mathrm{Fe}, \mathrm{Ni}, \mathrm{Cu}$, and $\mathrm{Pb}$ ) in Burullus Lake water

Seasonal variation of heavy metal distribution in Burullus Lake water and for $O$. niloticus muscles

The results presented in Table 8 revealed that there were no significant variations $(p=0.842)$ in the seasonal mean values of $\mathrm{Mn}$ among winter and summer seasons, where the lowest value $(1.03 \mu \mathrm{g} / \mathrm{L})$ was obtained in winter season and the highest one $(1.15 \mu \mathrm{g} / \mathrm{L})$ was in summer season. It can be also noticed that the mean values of $\mathrm{Zn}$ exhibited a significant variations $(p=0.041)$ among winter and summer seasons. However, the lowest value $(4.01 \mu \mathrm{g} / \mathrm{L})$ was found in the summer season, and the highest value $(17.00 \mu \mathrm{g} / \mathrm{L})$ was in the winter season. It is clear that there was a significant variation $(p=0.038)$ in the seasonal mean values of Fe values in water, where the lowest seasonal mean value $(14.05 \mu \mathrm{g} / \mathrm{L})$ was recorded in the winter season and the highest $(44.70 \mu \mathrm{g} / \mathrm{L})$ was in summer.

There was a significant variation $(p<0.0001)$ in the seasonal mean values of $\mathrm{Ni}$ values in water, where the lowest seasonal mean value $(3.66 \mu \mathrm{g} / \mathrm{L})$ was obtained in the winter season and the highest one $(10.08 \mu \mathrm{g} / \mathrm{L})$ was in summer. The obtained data revealed that seasonal mean values of $\mathrm{Cu}$ values in water not varied significantly $(p=0.108)$ among winter and summer seasons, where the lowest value $(1.64 \mu \mathrm{g} / \mathrm{L})$ was recorded in the winter season and the highest one $(2.46 \mu \mathrm{g} / \mathrm{L})$ was in the summer season. Seasonal mean values of $\mathrm{Pb}$ in lake water showed a significant difference $(p=0.030)$ among winter and summer seasons, where the highest value was $8.07 \mu \mathrm{g} / \mathrm{L}$ in the summer season and the lowest mean value was $1.80 \mu \mathrm{g} / \mathrm{L}$ in water during winter season.

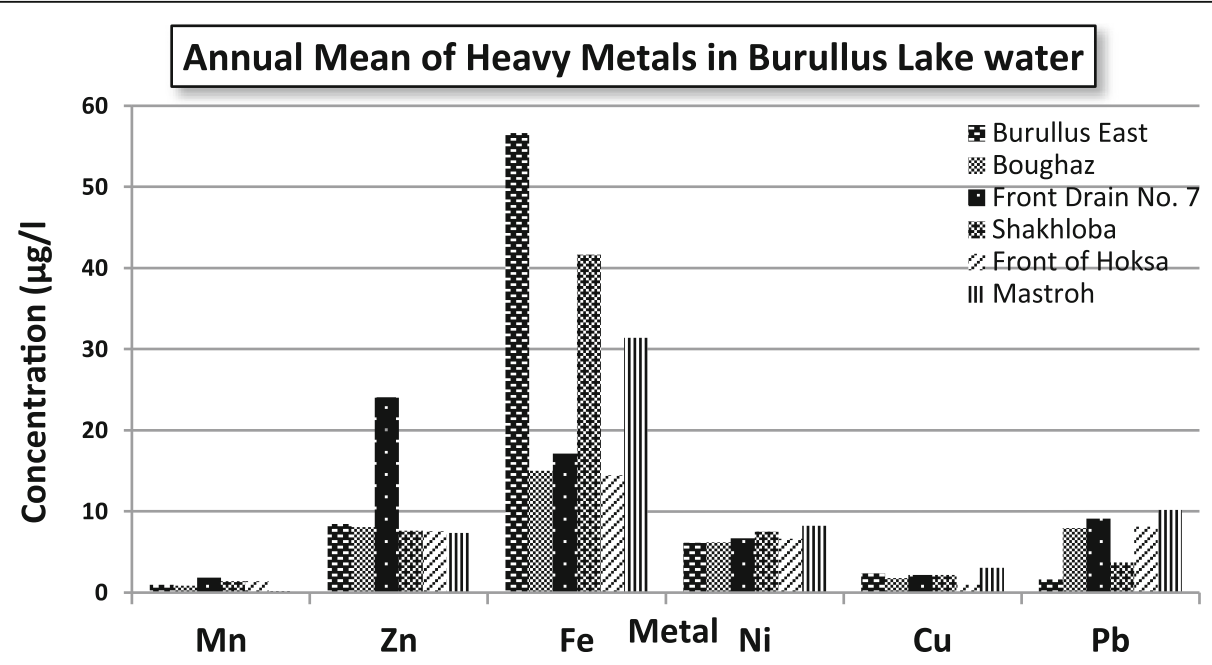

Fig. 2 Annual mean of heavy metal concentration $(\mu \mathrm{g} / \mathrm{L})$ in water at each selected site of Burullus Lake during 2014 
Table 5 Mean values of heavy metals ( $\mu \mathrm{g} / \mathrm{g}$ wet wt.) in O. niloticus muscles at Burullus Lake during winter and summer 2014

\begin{tabular}{|c|c|c|c|c|c|c|c|c|c|c|c|c|}
\hline \multirow[t]{2}{*}{ Location } & \multicolumn{6}{|c|}{ Winter } & \multicolumn{6}{|c|}{ Summer } \\
\hline & $\overline{\mathrm{Mn}}$ & $\mathrm{Zn}$ & $\mathrm{Fe}$ & $\mathrm{Ni}$ & $\mathrm{Cu}$ & $\mathrm{Pb}$ & $\overline{M n}$ & $\mathrm{Zn}$ & $\mathrm{Fe}$ & $\mathrm{Ni}$ & $\mathrm{Cu}$ & $\overline{\mathrm{Pb}}$ \\
\hline Eastern sector & 1.34 & 4.46 & 11.85 & 0.52 & 0.46 & 0.21 & 0.33 & 3.64 & 8.71 & 0.64 & 0.29 & 0.39 \\
\hline Middle sector & 0.71 & 4.37 & 17.66 & 0.43 & 0.53 & 0.62 & 0.27 & 4.13 & 8.69 & 0.58 & 0.40 & 0.39 \\
\hline Western sector & 1.24 & 5.35 & 10.44 & 0.46 & 0.37 & 0.81 & 0.21 & 6.23 & 6.39 & 0.47 & 0.28 & 0.33 \\
\hline
\end{tabular}

Table 8 and Fig. 4b represent the seasonal distribution of the metal concentration in muscle fish tissues. It can be observed that there was a significant variation $(p<0.0001)$ in the seasonal mean values of Mn among winter and summer seasons, where the lowest value $(0.27 \mu \mathrm{g} / \mathrm{g}$ wet wt.) was obtained in the summer season, while the highest one $(1.10 \mu \mathrm{g} / \mathrm{g}$ wet wt.) was in the winter season. Seasonal variation of $\mathrm{Zn}$ in muscle tissues showed insignificant difference $(p=0.937)$, where the highest value $(4.73 \mu \mathrm{g} / \mathrm{g}$ wet wt.) was recorded in winter and the lowest value $(4.67 \mu \mathrm{g} / \mathrm{g}$ wet wt.) was in summer.

The data presented in Table 8 revealed that the seasonal mean values of Fe concentration in muscles varied significantly $(p=0.001)$ among winter and summer, where the lowest value $(7.93 \mu \mathrm{g} / \mathrm{g}$ wet wt.) was found in summer and the highest value $(13.32 \mu \mathrm{g} / \mathrm{g}$ wet wt.) was in winter. It can be also noticed that there was a significant difference $(p=0.012)$ for the seasonal mean values of $\mathrm{Ni}$ values among winter and summer seasons, where the lowest value $(0.47 \mu \mathrm{g} / \mathrm{g}$ wet wt.) was obtained in the winter season and the highest one $(0.56 \mu \mathrm{g} / \mathrm{g}$ wet wt.) was in summer. The seasonal mean values of $\mathrm{Cu}$ concentration in muscles varied significantly $(p=0.002)$ among winter and summer seasons, where the lowest value $(0.32 \mu \mathrm{g} / \mathrm{g}$ wet wt.) was obtained in summer and the highest value $(0.45 \mu \mathrm{g} / \mathrm{g}$ wet wt. $)$ was in winter. Table 8 shows that seasonally, there were no significant variations $(p=0.066)$ of $\mathrm{Pb}$ values in muscles, where the highest value $(0.63 \mu \mathrm{g} / \mathrm{g}$ wet wt.) was found in winter and the lowest one $(0.37 \mu \mathrm{g} / \mathrm{g}$ wet wt.) was in summer.

According to the seasonal distribution of the metal concentration in Burullus Lake water, it can be noticed that all metals, except $\mathrm{Zn}$, exhibited their highest values during summer season (Table 8 and Fig. 4a). However, all metals, except $\mathrm{Ni}$, exhibited their highest value in fish muscles during winter season (Table 8 and Fig. 4a).

\section{Analysis of heavy metals ( $\mathrm{Mn}, \mathrm{Zn}, \mathrm{Fe}, \mathrm{Ni}, \mathrm{Cu}$, and $\mathrm{Pb}$ ) in Burullus Lake water}

The Pearson's correlation coefficient $(r)$ was calculated to determine if some of these metals were interrelated with each other, and the results are presented in Table 9.The results showed that there were no significant $(P>0.05)$ correlation between concentration of $\mathrm{Mn}$ and other studied heavy metals in water. $\mathrm{Zn}$ had a negative significant $(P \leq 0.05)$ correlation between concentrations of $\mathrm{Zn}$ and concentrations of $\mathrm{Ni}$ and $\mathrm{Pb}$, while $\mathrm{Fe}$ had a positive significant $(P \leq 0.05)$ correlation between its concentration and two other elements $(\mathrm{Ni}$ and $\mathrm{Cu})$ in water. The results presented in Table 9 revealed that $\mathrm{Ni}$ and $\mathrm{Pb}$ had a positive significant $(P \leq 0.05)$ correlation between their concentrations in water during winter and summer seasons.

\section{Estimation of heavy metal ( $\mathrm{Mn}, \mathrm{Zn}, \mathrm{Fe}, \mathrm{Ni}, \mathrm{Cu}$, and $\mathrm{Pb}$ ) bioconcentration for $\mathrm{O}$. niloticus fish in Burullus Lake}

The bioconcentration factors (BCFs) of the heavy metals in the muscles of $O$. niloticus fish in the eastern, middle, and western sectors of Burullus Lake are presented in Table 10. It was observed that the eastern sector had the highest BCFs of Mn (803.83) and $\mathrm{Ni}$ (94.77) while the western sector had the highest BCFs of $\mathrm{Zn}$ (765.87), Fe (582.70), and $\mathrm{Cu}$ (351.65). The maximum BCF of lead (122.94) was observed at the middle sector.

\section{Determining the contamination factor (CF), pollution load index (PLI), and metal pollution index (MPI) for 0 . niloticus fish in Burullus Lake}

The values of the contamination factor (CF), pollution load index (PLI), and metal pollution index (MPI) for $O$. niloticus fish collected from Burullus Lake are presented in Table 11. The obtained data for CF in fish samples showed the range of 1.00-1.90. The present study area shows PLI values between 1.20 and 1.28 for fish samples with maximum at the middle sector and minimum at

Table 6 Descriptive statistics of heavy metal values in O. niloticus muscles ( $\mu \mathrm{g} / \mathrm{g}$ wet wt.) at Burullus Lake during winter and summer 2014

\begin{tabular}{|c|c|c|c|c|c|c|}
\hline Metal & $\mathrm{Mn}$ & $\mathrm{Zn}$ & $\mathrm{Fe}$ & $\mathrm{Ni}$ & $\mathrm{Cu}$ & $\mathrm{Pb}$ \\
\hline $\operatorname{Max}$ & 1.34 & 6.23 & 17.66 & 0.64 & 0.53 & 0.81 \\
\hline Min & 0.21 & 3.64 & 6.39 & 0.43 & 0.28 & 0.21 \\
\hline Annual mean \pm SD & $0.68 \pm 0.5$ & $4.70 \pm 0.94$ & $10.62 \pm 3.91$ & $0.52 \pm 0.08$ & $0.39 \pm 0.1$ & $0.46 \pm 0.22$ \\
\hline$P$ value & 0.348 & 0.107 & 0.083 & 0.037 & 0.021 & 0.095 \\
\hline
\end{tabular}


Table 7 Annual mean \pm SD of heavy metals ( $\mu \mathrm{g} / \mathrm{g}$ wet wt.) in O. niloticus muscles from Burullus Lake

\begin{tabular}{lllllll}
\hline Location & $\mathrm{Mn}$ & $\mathrm{Zn}$ & $\mathrm{Fe}$ & $\mathrm{Ni}$ & $\mathrm{Cu}$ & $\mathrm{Pb}$ \\
\hline Eastern sector & $0.84 \pm 0.65^{\mathrm{a}}$ & $4.05 \pm 0.73^{\mathrm{a}}$ & $10.28 \pm 3.82^{\mathrm{ab}}$ & $0.58 \pm 0.11^{\mathrm{a}}$ & $0.37 \pm 0.14^{\mathrm{ab}}$ & $0.33 \pm 0.13^{\mathrm{a}}$ \\
Middle sector & $0.49 \pm 0.26^{\mathrm{a}}$ & $4.25 \pm 0.82^{\mathrm{a}}$ & $13.18 \pm 6.14^{\mathrm{a}}$ & $0.51 \pm 0.11^{\mathrm{ab}}$ & $0.47 \pm 0.08^{\mathrm{a}}$ & $0.56 \pm 0.31^{\mathrm{a}}$ \\
Western sector & $0.72 \pm 0.60^{\mathrm{a}}$ & $5.79 \pm 3.15^{\mathrm{a}}$ & $8.42 \pm 3.32^{\mathrm{b}}$ & $0.46 \pm 0.06^{\mathrm{b}}$ & $0.32 \pm 0.09^{\mathrm{b}}$ & $0.57 \pm 0.28^{\mathrm{a}}$ \\
*PL $(\mu \mathrm{g} / \mathrm{g} \text { wet } w \mathrm{t} .)^{\mathrm{P} \text { value }}$ & 1 & 100 & 100 & $0.5-1$ & 30 & 2 \\
\hline
\end{tabular}

Means in the columns followed by different letters are significantly different (Duncan's multiple range test $P<0.05$ ). Superscript letters a, $b$, and $c$ show differences among locations. *PL (permissible limits) (average daily intake in wet wt.) according to WHO guidelines, 1989 (Mokhtar, 2009 )

eastern sector. The MPI values varied from 1.15 to 1.22 in fish samples.

\section{Comparing between concentrations of heavy metals in} Burullus Lake of the present study with the previous studies The comparison between values of heavy metals of both water and $O$. niloticus muscle tissues in Burullus Lake water of the present study with those results of the previous studies is presented in Tables 12 and 13 .

\section{Discussion}

Burullus Lake is considered a big water pond affected by different sources of pollution. Therefore, the local variation of metals was not obviously clear and showed metal-specific area, with slight low concentration at Boughaz and Mastroh sites which are relatively far away from pollution sources.

Heavy metals in the water of Burullus Lake followed the order $\mathrm{Fe}>\mathrm{Zn}>\mathrm{Ni}>\mathrm{Pb}>\mathrm{Cu}>\mathrm{Mn}$. High levels of Fe in the water of Burullus Lake could be due to Fe release from sediments as sulphides (Abo El Ella et al., 2005). Zinc is sometimes released into the aquatic environment in considerable amounts. Zinc is harmful at lower sub-lethal values, particularly after extended exposure (Bryan and Langston, 1992; UNEP, 1993). Nickel is a fairly movable metal in natural waters. Generally, values of soluble nickel are less than those of suspended and bed sediments (USPHS, 2005). The highest value of $\mathrm{Pb}$ may be resulted from heavy agricultural runoff containing fertilizers, agrochemicals, and pesticides and from gasoline containing $\mathrm{Pb}$ from the fishery boats. Copper is one of the most common contaminants related to urban runoff and antifouling paint. It is generally utilized as herbicidal producing component (Kennish, 1996). When Mn values in natural waters exceeded $0.2 \mathrm{mg} / \mathrm{l}$, this can often be attributed to anthropogenic activities, rather than natural enrichment of the water by Mn (Nagpal, 2001). Manganese toxicity in aquatic environment is impacted by several factors such as salinity, water hardness, $\mathrm{pH}$, and the occurrence of other contaminants.

The highest values of $\mathrm{Fe}$ in lake water samples collected from Burullus East site can be attributed to the decrease in the $\mathrm{pH}$ of the water at the eastern area due to the growth of aquatic plants where $\mathrm{CO}_{2}$ is liberated with high rates as a result of the respiration of such

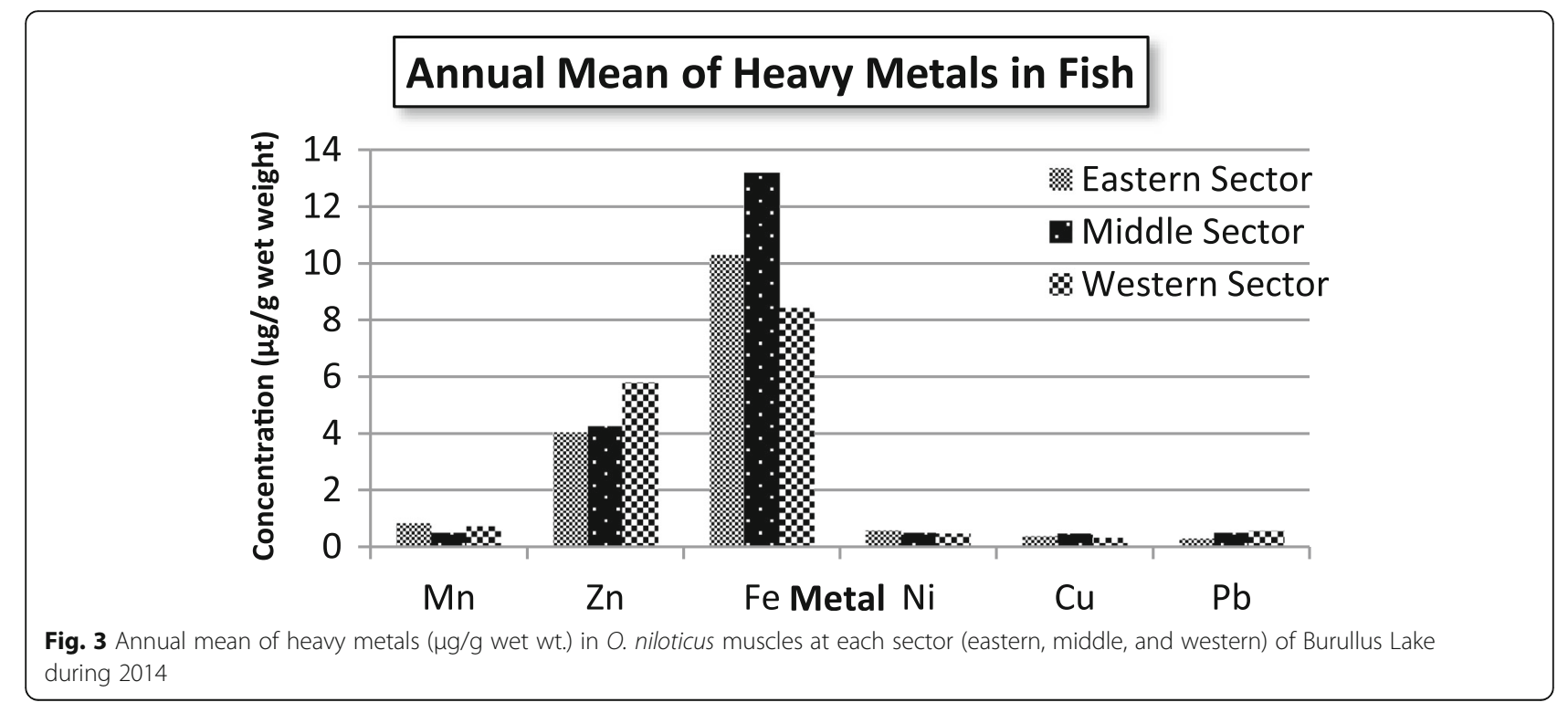


Table 8 Seasonal mean \pm SD of heavy metals in water $(\mu \mathrm{g} / \mathrm{L})$ and in O. niloticus muscles $(\mu \mathrm{g} / \mathrm{g}$ wet wt.) from Burullus Lake during 2014

\begin{tabular}{|c|c|c|c|c|c|c|c|c|c|c|c|c|}
\hline \multirow[t]{2}{*}{ Season } & \multicolumn{6}{|l|}{ Water } & \multicolumn{6}{|l|}{ Fish } \\
\hline & $\overline{M n}$ & $\mathrm{Zn}$ & $\mathrm{Fe}$ & $\mathrm{Ni}$ & $\mathrm{Cu}$ & $\mathrm{Pb}$ & $\mathrm{Mn}$ & $\mathrm{Zn}$ & $\mathrm{Fe}$ & $\mathrm{Ni}$ & $\mathrm{Cu}$ & $\mathrm{Pb}$ \\
\hline Winter & $\begin{array}{l}1.03 \pm \\
0.96\end{array}$ & $\begin{array}{l}17.0 \pm \\
13.49\end{array}$ & $\begin{array}{l}14.05 \pm \\
5.44\end{array}$ & $3.66 \pm 0.70$ & $\begin{array}{l}1.64 \pm \\
0.77\end{array}$ & $\begin{array}{l}1.80 \pm \\
1.54\end{array}$ & $\begin{array}{l}1.10 \pm \\
0.47\end{array}$ & $\begin{array}{l}4.73 \pm \\
0.87\end{array}$ & $\begin{array}{l}13.32 \pm \\
4.04\end{array}$ & $\begin{array}{l}0.47 \pm \\
0.09\end{array}$ & $\begin{array}{l}0.45 \pm \\
0.12\end{array}$ & $\begin{array}{l}0.55 \pm \\
0.31\end{array}$ \\
\hline Summer & $\begin{array}{l}1.15 \pm \\
1.01\end{array}$ & $4.01 \pm 1.18$ & $\begin{array}{l}44.70 \pm \\
30.9\end{array}$ & $\begin{array}{l}10.08 \pm \\
1.13\end{array}$ & $\begin{array}{l}2.46 \pm \\
0.83\end{array}$ & $\begin{array}{l}8.07 \pm \\
3.73\end{array}$ & $\begin{array}{l}0.27 \pm \\
0.07\end{array}$ & $\begin{array}{l}4.67 \pm \\
2.77 \pm\end{array}$ & $7.93 \pm 4.13$ & $\begin{array}{l}0.56 \pm \\
0.09\end{array}$ & $\begin{array}{l}0.32 \pm \\
0.09\end{array}$ & $\begin{array}{l}0.37 \pm \\
0.18\end{array}$ \\
\hline$p$ value & 0.842 & 0.041 & 0.038 & $<0.0001$ & 0.108 & 0.030 & $<0.0001$ & 0.937 & 0.001 & 0.012 & 0.002 & 0.066 \\
\hline
\end{tabular}

plants and there is a matter of fact that Fe may be assimilated from both water and sediments by plants grow intensively at the lakes. However, the higher values of $\mathrm{Mn}$ and $\mathrm{Zn}$ in lake water samples collected from the front of Drain No. 7 site indicates that the Drain No. 7 located at the southern part of the lake discharge its drainage water with higher concentrations of $\mathrm{Mn}$ and $\mathrm{Zn}$ in comparison with the water discharged eastern and western parts of the lake. As well as, the higher concentrations of $\mathrm{Ni}, \mathrm{Cu}$, and $\mathrm{Pb}$ at Mastroh site may be resulted from boat activities that include disposal of liquid wastes and use of paints, also the agriculture wastewater from Zaghlol drain that located near from Mastroh station.

Heavy metals in the muscles of O. niloticus fish of Burullus Lake followed the order $\mathrm{Fe}>\mathrm{Zn}>\mathrm{Mn}>\mathrm{Ni}>\mathrm{Pb}>$ $\mathrm{Cu}$. Fish muscle is the edible part of fish and frequently employed in assessing human health risks in relation to fish consumption. There is a metal-specific area according to the type of the pollution source. Generally, $\mathrm{Mn}$ and $\mathrm{Ni}$ recorded their highest values in fish muscles from the eastern sector; $\mathrm{Zn}$ and $\mathrm{Pb}$ were found in the western sector, while the maximum values of $\mathrm{Fe}$ and $\mathrm{Cu}$ were in the middle sector. The essential metals, such as iron, zinc, copper, and manganese are in higher values, presumably due to their function as co-factors for the activation of a number of enzymes and regulated to maintain a certain homeostatic status in fish. On the other hand, the non- essential metals have no biological function or requirement, and its values in fishes are generally low (Kumar et al., 2011). The values of $\mathrm{Mn}$ in fish muscles were lower than those obtained in muscle tissues of Nile tilapia (7.66 $\mu \mathrm{g} / \mathrm{g}$ wet wt.) from some fish farms in El-Fayoum province (Ali and Abdel-Satar, 2005).

In Burullus Lake water, all metals, except $\mathrm{Zn}$, exhibited their highest values during summer season. This may be attributed to agricultural runoff, which may carry higher values of these metals and arise from anthropogenic activities such as the use of chemical fertilizers and pesticides in agriculture land. While in fish muscles, all metals, except $\mathrm{Ni}$, exhibited their highest value during winter season. The higher metal content in muscles in winter may be a result from considerable rainfall which washed down the wastes (Dural et al,, 2007; Saei-Dehkordi and Fallah, 2011). The bioavailability of metals may be influenced by physiological activities of fish during different seasons (TekinÖzan and Kir, 2008). Different season-dependent conditions such as salinity, $\mathrm{pH}$ and hardness, dietary factors, and growth and reproductive cycles are also influential on metal accumulation in fish tissues (Yilmaz et al., 2010 and SaeiDehkordi and Fallah, 2011). These results are in agreement with Authman et al. (2013), who found that metal concentration in fish organs exhibited seasonal variations due to the increase or decrease of drainage water discharged into the canals.

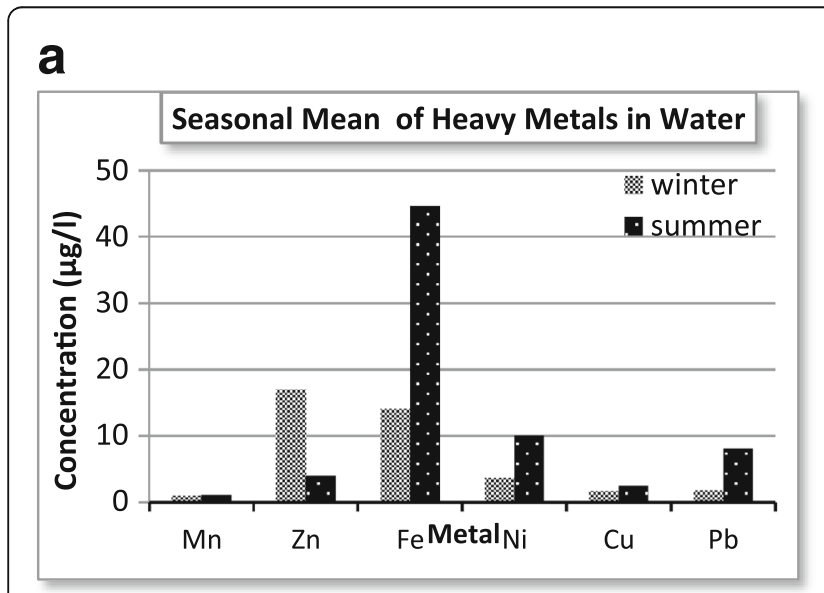

b

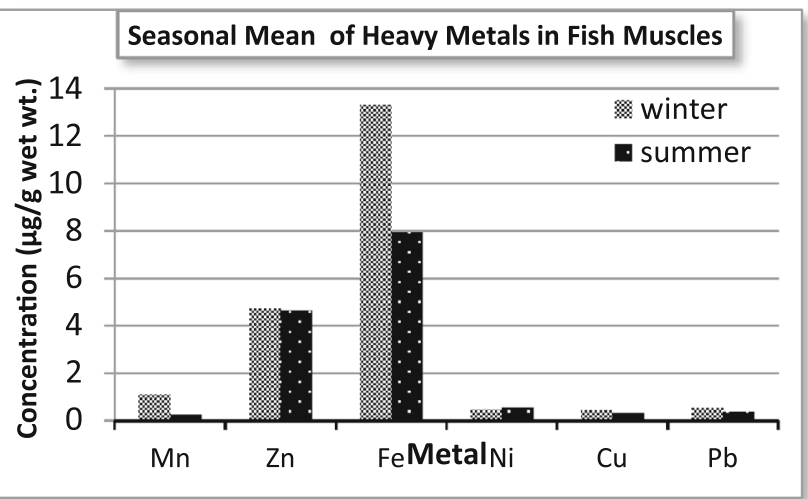

Fig. 4 Seasonal mean of heavy metals in a water ( $\mu \mathrm{g} / \mathrm{L})$ and $\mathbf{b}$ in O. niloticus muscles ( $\mu \mathrm{g} / \mathrm{g}$ wet wt.) from Burullus Lake during winter and summer 2014 
Table 9 The Pearson's correlation coefficient ( $r$ ) between heavy metals in water

\begin{tabular}{lllllll}
\hline Metal & $\mathrm{Mn}$ & $\mathrm{Zn}$ & $\mathrm{Fe}$ & $\mathrm{Ni}$ & $\mathrm{Cu}$ & $\mathrm{Pb}$ \\
\hline $\mathrm{Mn}$ & 1 & & & & & \\
$\mathrm{Zn}$ & 0.267 & 1 & & & & \\
$\mathrm{Fe}$ & 0.214 & -0.366 & 1 & & & \\
$\mathrm{Ni}$ & -0.040 & $-0.612^{*}$ & $0.589^{*}$ & 1 & & \\
$\mathrm{Cu}$ & -0.007 & -0.109 & $0.592^{*}$ & 0.554 & 1 & \\
$\mathrm{~Pb}$ & 0.088 & $-0.724^{*}$ & -0.115 & $0.709^{*}$ & 0.401 & 1 \\
\hline
\end{tabular}

${ }^{*}$ Correlation is significant at $p$ value $<0.05$

The non-significant correlation of Mn concentration and the negative correlation of $\mathrm{Zn}$ concentration with the concentration of the other studied metals in water may be due to the source of $\mathrm{Mn}$ and $\mathrm{Zn}$ (agricultural and domestic sewage) which is not similar to the source of the other studied heavy metals. The positive relationship indicates that the source of $\mathrm{Fe}, \mathrm{Ni}, \mathrm{Cu}$, and $\mathrm{Pb}$ (industrial) input in Burullus Lake is similar. So we can noticed that the higher concentrations of $\mathrm{Mn}$ and $\mathrm{Zn}$ are found in the southern region of the lake, while the higher concentrations of $\mathrm{Fe}, \mathrm{Ni}, \mathrm{Cu}$, and $\mathrm{Pb}$ are found mostly in the eastern region of the lake.

The estimation of biological status (biological monitoring), especially of the fish communities, is important for monitoring and the assessment of overall integrative ecological status of natural water bodies and specific aquatic environments (Bervoets and Blust, 2003; Ben salem et al., 2014). The high bioconcentration factors (BCFs) of heavy metals in the muscles of O. niloticus fish may reflect the large release of heavy metals to the environment due to domestic and industrial runoff. However, these high concentrations are also a result of the major environmental conditions of most aquatic ecosystems (slight acidity and moderately high organic matter) which favor high rates of bioavailability and therefore accumulation in the food chain.

Jezierska and Witeska (2006) concluded that the difference in the amounts of various metal ion accumulation in fish body result from different affinity of metals to fish tissues, different uptake, deposition, and excretion rates. Studies related to the bioaccumulation of metals in tissues demonstrated the variation of metal accumulations (Watanabe et al., 2003, Masoud et al., 2007 and Younis

Table 10 Bioconcentration factors (BCFs) of heavy metals in muscles of Oreochromis niloticus fish

\begin{tabular}{lllllll}
\hline Location & \multicolumn{6}{l}{$\mathrm{BCFs}$} \\
\cline { 2 - 7 } & $\mathrm{Mn}$ & $\mathrm{Zn}$ & $\mathrm{Fe}$ & $\mathrm{Ni}$ & $\mathrm{Cu}$ & $\mathrm{Pb}$ \\
\hline Eastern sector & 803.83 & 493.00 & 286.99 & 94.77 & 181.37 & 69.25 \\
Middle sector & 449.54 & 326.67 & 438.60 & 68.32 & 192.62 & 122.94 \\
Western sector & 537.31 & 765.87 & 582.70 & 69.70 & 351.65 & 70.37 \\
\hline
\end{tabular}

Table 11 Values of the contamination factor (CF), pollution load index (PLI), and metal pollution index (MPI) for O. niloticus fish collected from Burullus Lake

\begin{tabular}{|c|c|c|c|c|c|c|c|c|}
\hline \multirow[t]{2}{*}{ Location } & \multicolumn{6}{|l|}{ CF } & \multirow[t]{2}{*}{ PLI } & \multirow[t]{2}{*}{ MPI } \\
\hline & $\mathrm{Mn}$ & $\mathrm{Zn}$ & $\mathrm{Fe}$ & $\mathrm{Ni}$ & $\mathrm{Cu}$ & $\mathrm{Pb}$ & & \\
\hline Eastern sector & 1.71 & 1.00 & 1.22 & 1.23 & 1.15 & 1.00 & 1.20 & 1.15 \\
\hline Middle sector & 1.00 & 1.05 & 1.57 & 1.09 & 1.42 & 1.70 & 1.28 & 1.22 \\
\hline Nestern sector & 1.49 & 1.43 & 1.00 & 1.00 & 1.00 & 1.90 & 1.26 & 1.20 \\
\hline
\end{tabular}

et al., 2015). Moreover, Koca et al. (2005) postulated that the accumulation patterns of contaminants in fish and other aquatic organisms depend on both uptake and elimination rates of contaminants. Bioaccumulation of metals may lead to high mortality rate or cause many biochemical and histological alterations in the survived fish (Rashed, 2001a; Rashed, 2001b and Soltan et al., 2005). It has been indicated that BCFs from environment to fish tissue changes according to the species of the chemical, the metabolite properties of the tissues, and the pollution degree of the environment (Ayas, 2007; Ozmen et al., 2008 and Younis et al., 2015).

The degree of contamination from heavy metals could be evaluated by determining the contamination factor (CF), pollution load index (PLI), and metal pollution index (MPI) (Tomlinson et al., 1980 and Usero et al., 2005). The PLI gives an evaluation of the overall toxicity status of the sample, and also, it is a consequence of the contribution of the studied metals $(\mathrm{Mn}, \mathrm{Zn}, \mathrm{Fe}, \mathrm{Ni}, \mathrm{Cu}$, and $\mathrm{Pb})$. In addition, MPI can also be used to assess the quality of the coastal areas and compare the total metal content in the different compartments of the studied area.

Burullus Lake referred a moderate contamination area as the obtained data for $\mathrm{CF}$ in fish samples showed the range of 1.00-1.90. According to Tomlinson et al. (1980), the obtained PLI values indicate progressive decline in the quality of the present investigated sectors of Burullus Lake. MPI was previously used to evaluate the metal contamination in different marine organisms and compare its degree between locations and within different species (Giusti et al., 1999; Hamed and Emara, 2006; Ibrahim and Abu El-Regal, 2014; Abdel-Salam and Hamdi, 2014; and El-Moselhy et al., 2016). According to the estimated data resulting from contamination factor and pollution indices (PLI and MPI), the degree of contamination in the present area by using $O$. niloticus fish can be classified as follows: middle sector $>$ western sector $>$ eastern sector.

It could be observed from the comparison between values of heavy metals of both water and O. niloticus muscle tissues in Burullus Lake water of the present study with those results of the previous studies that the annual mean of Mn detected in water $(1.09 \mu \mathrm{g} / \mathrm{L})$ was lower than that recorded by Saeed and Shaker (2008), while other studied metals were in the range of the previous studies. 
Table 12 Comparison between heavy metal concentrations of $(\mu \mathrm{g} / \mathrm{L})$ in Burullus Lake water of the present study with the previous studies

\begin{tabular}{|c|c|c|c|c|c|c|}
\hline \multirow[t]{2}{*}{ References } & \multicolumn{6}{|c|}{ Heavy metal values $(\mu \mathrm{g} / \mathrm{L})$ in water } \\
\hline & $\mathrm{Mn}$ & $\mathrm{Zn}$ & $\mathrm{Fe}$ & $\mathrm{Ni}$ & $\mathrm{Cu}$ & $\mathrm{Pb}$ \\
\hline Beltagy (1985) & - & - & 250 & - & 2.66 & - \\
\hline Abdelmoneim et al., (1990) & - & 9.23 & - & - & 2.56 & 2.15 \\
\hline Radwan (2000) & - & 6.76 & 246 & - & 3.52 & 2.67 \\
\hline Farag (2002) & - & 190.00 & 240 & - & 50.00 & 60.00 \\
\hline Radwan and Lotfy (2002) & - & 7.5 & 580 & - & 5.80 & 3.50 \\
\hline Radwan and Shakweer (2004) & - & 11.07 & 1031 & 3.73 & 8.48 & 5.00 \\
\hline Radwan (2005) & - & 15.68 & 1920 & 4.13 & 12.43 & 7.30 \\
\hline Saeed and Shaker (2008) & 194.00 & 50.00 & 425 & - & 35.00 & 65.00 \\
\hline Basiony (2009) & - & - & - & - & 13.89 & 79.90 \\
\hline Masoud et al. (2011) & - & 30.75 & 17,370 & - & 3.30 & 4.13 \\
\hline Basiony (2014) & - & 64.15 & 1550 & 26.58 & 23.42 & 12.07 \\
\hline El-Alfy (2015) & - & 2.92 & 14.64 & - & 7.28 & 8.88 \\
\hline The present study & 1.09 & 10.50 & 29.38 & 6.87 & 2.05 & 5.98 \\
\hline
\end{tabular}

Also, the values of $\mathrm{Mn}, \mathrm{Zn}$, and Ni detected in O. niloticus muscle tissues were lower than ones recorded by other studies, while $\mathrm{Fe}, \mathrm{Cu}$, and $\mathrm{Pb}$ were in the range of the previous studies.

The concentrations of metals in water and O. niloticus fish are generally accepted by the international legislation limits. Generally, the value of metals detected in water was lower than those recorded by EPA (2002) for the permissible limits of heavy metals, whereas the concentrations of heavy metals detected in O. niloticus muscles were within the permissible concentrations (PL) recommended by the World Health Organization (WHO) (Mokhtar, 2009).

\section{Conclusions}

Burullus Lake has received a great attention because of its environmental and economic importance for being a significant source of fish production in Egypt. The study was designed to evaluate some metal pollution in Burullus Lake. The values of heavy metals $(\mathrm{Mn}, \mathrm{Zn}, \mathrm{Fe}, \mathrm{Ni}, \mathrm{Cu}$, and

Table 13 Comparison of heavy metal values in muscles of $O$. niloticus fish with previous studies in northern lakes and other localities

\begin{tabular}{llllllll}
\hline References & \multicolumn{6}{c}{ Heavy metal $(\mu \mathrm{g} / \mathrm{g})$ in fish muscles } \\
\cline { 2 - 8 } & $\mathrm{Mn}$ & $\mathrm{Zn}$ & $\mathrm{Fe}$ & $\mathrm{Ni}$ & $\mathrm{Cu}$ & $\mathrm{Pb}$ \\
\hline El-Moselhy (1999) & - & 5.96 & 4.32 & - & 0.51 & 0.13 \\
Radwan and Shakweer (2004) & - & 19.26 & - & 6.31 & 4.9 & 7.64 \\
Saeed and Shaker (2008) & - & 9.88 & 21.44 & - & 1.77 & 0.016 \\
Basiony (2009) & - & - & - & - & 1.43 & 6.45 \\
Basiony (2014) & - & 18.7 & 27.14 & 1.45 & 0.36 & 1.29 \\
The present study & 0.68 & 4.70 & 10.62 & 0.52 & 0.39 & 0.46 \\
\hline
\end{tabular}

$\mathrm{Pb}$ ) were measured in lake water and muscles of fish (Oreochromis niloticus) during winter and summer 2014.

In the present study, the obtained values of metals $(\mathrm{Mn}$, $\mathrm{Zn}, \mathrm{Fe}, \mathrm{Ni}, \mathrm{Cu}$, and $\mathrm{Pb}$ ) in water samples varied among different sites. The front of Drain No. 7 (site 3) has the highest values of $\mathrm{Mn}$ and $\mathrm{Zn}$ while Mastroh (site 6) has the highest values of $\mathrm{Ni}, \mathrm{Cu}$, and $\mathrm{Pb}$. In addition, the highest value of Fe was at Burullus East (site1). The values of heavy metals in surface water of Burullus Lake during the year 2014 were follow the order $\mathrm{Fe}>\mathrm{Zn}>\mathrm{Ni}>\mathrm{Pb}>\mathrm{Cu}>\mathrm{Mn}$. The value of the studied metals ( $\mathrm{Mn}, \mathrm{Zn}, \mathrm{Fe}, \mathrm{Ni}, \mathrm{Cu}$, and $\mathrm{Pb}$ ) in fish Oreochromis niloticus varied among different sectors. The middle and eastern sectors of Burullus Lake have higher concentrations of heavy metals than the western sector which attributed to the occurrence of many drains carrying sewage and agricultural waste at these sectors. The order of heavy metals in the muscles of O. niloticus fish of Burullus Lake was $\mathrm{Fe}>\mathrm{Zn}>\mathrm{Mn}>\mathrm{Ni}>\mathrm{Pb}>\mathrm{Cu}$.

It was found that the eastern sector had the highest bioconcentration factors (BCFs) of $\mathrm{Mn}$ and $\mathrm{Ni}$ while the western sector has the highest BCFs of $\mathrm{Zn}, \mathrm{Fe}$, and $\mathrm{Cu}$. The maximum BCF of lead was observed at the middle sector. In addition, contamination factor (CF) and pollution indices (PLI and MPI) of Oreochromis niloticus were used to determine the degree of heavy metal pollution at the different sectors and indicated that the investigated area referred moderate contamination area. The obtained PLI values indicating progressive decline in the quality of the present investigated sectors of Burullus Lake.

Health risk analysis of heavy metals in the edible parts of the fish indicated safe concentrations for human consumption, and values in the muscles are generally accepted by the international legislation limits. The 
concentrations of metals in water and Oreochromis niloticus fish should be continuously monitored to keep it safe, as well as the wastewater must be treated before being drained into the lake. In addition, cooperation between different authorities and efforts are needed to protect the biodiversity in Burullus Lake.

\section{Abbreviations}

BCFs: Bioconcentration factors; CF: Contamination factor; MPI: Metal pollution index; PLI: Pollution load index

\section{Acknowledgements}

We declare that we have no acknowledgements.

\section{Funding}

We declare that there are no funding sources.

\section{Availability of data and materials}

Not applicable.

\section{Authors' contributions}

OAE designed the work and wrote the manuscripts. MIE drafted the manuscript. LIM did heavy metal analysis and drafted the manuscript. DHD performed the experimental work. KhME proposed the research idea and drafted the manuscript. All authors read and approved the final manuscript.

\section{Ethics approval}

We declare that we do not need an ethics approval regarding our work on Tilapia fish (Oreochromis niloticus).

\section{Consent for publication}

Not applicable.

\section{Competing interests}

The authors declare that they have no competing interests.

\section{Publisher's Note}

Springer Nature remains neutral with regard to jurisdictional claims in published maps and institutional affiliations.

\section{Author details}

${ }^{1}$ Department of Environmental Sciences, Faculty of Science, Damietta University, New Damietta City, Damietta 34517, Egypt. ${ }^{2}$ Environmental Division, National Institute of Oceanography and Fisheries, Suez, Egypt.

Received: 30 May 2017 Accepted: 29 January 2018

Published online: 14 February 2018

\section{References}

Abdelmoneim, M. A., El-Sarraf, W. M., \& Beltagy, A. I. (1990). Distribution of some heavy metals in Lake Burullus, Egypt. Bulletin of the National Institute of Oceanography and Fisheries, Egyptian Journal of Aquatic Research, 16(1), 203-221.

Abdel-Salam, H. A., \& Hamdi, S. A. H. (2014). Heavy metals monitoring using commercially important crustaceans and mollusks collected from Egyptian and Saudi Arabia coasts. Animal and Veterinary sciences, 2(3), 49-61.

Abo El Ella, S. M., Hosny, M. M., \& Bakry, M. F. (2005). Utilizing fish and aquatic weeds infestation as bioindicators for water pollution in Lake Nubia, Sudan. Egyptian Journal of Aquatic Biology and Fisheries, 9, 63-84.

Ali, H. M., \& Abdel-Satar, M. A. (2005). Studies of some heavy metals in water, sediment, fish and fish diet in some fish farms in El-Fayoum Province, Egypt. Egyptian Journal of Aquatic Research, 2005., 31(2), 261-273.

Alinnor, I. J., \& Obiji, I. A. (2010). Assessment of trace metal composition in fish samples from Nworie River. Pakistan Journal of Nutrition, 9(1), 81-85.

Alne-na-ei, A. A. (2003). Contamination of irrigation and drainage canals and ponds in the Nile delta by heavy metals and its association with human health risks. Egyptian Journal of Zoology., 41, 47-60.

Al-SayeghPetkovšek, S., MazejGrudnik, Z., \& Pokorny, B. (2012). Heavy metals and arsenic concentrations in ten fish species from the šalek lakes (Slovenia): assessment of potential human health risk due to fish consumption. Environmental Monitoring and Assessment, 184, 2647-2662.

APHA (1999). American Public Health Association, Standard methods for the examination of water and wastewater, $20^{\text {th }}$ ed., Washington, DC, USA.

Authman, M. M. N., Abbas, H. H., \& Abbas, W. T. (2013). Assessment of metal status in drainage canal water and their bioaccumulation in Oreochromis niloticus fish in relation to human health. Environmental Monitoring and Assessment., 185, 891-907.

Ayas, Z. (2007). Trace element residues in eggshells of grey heron (Ardeacinerea) and black-crowned night heron (Nycticoraxnycticorax) from Nallihan Bird Paradise, Ankara-Turkey. Ecotoxicology, 16, 347-352.

Basiony, A. I. (2009). The environmental study on the pollution of Lake Burullus with heavy metals and organochlorine pesticides contaminants in water, sediment and fish. Scientific Report, Ministry of Higher Education, Egyptian National Commission for Unesco- Alesco- Isesco, Egypt.

Basiony, A. I. (2014). Environmental studies on heavy metals pollution and management of lake Burullus, Egypt. M. Sc. Thesis, Faculty of Science, Port Said University, Egypt.

Beltagy, I. A. (1985). Sequences and consequences of pollution in northern Egyptian Lakes. 1- Lake Borollus. Bulletin of the National Institute of Oceanography and Fisheries, 11, 73-97.

Ben Salem, Z., Capelli, N., Laffray, X., Elise, G., Ayadi, H., \& Aleya, L. (2014). Seasonal variation of heavy metals in water, sediment and roach tissues in a landfill draining system pond (Etueffont, France). Ecological Engineering., 69, 25-37.

Bervoets, L., \& Blust, R. (2003). Metal concentrations in water, sediment and gudgeon (Gobiogobio) from a pollution gradient: relationship with fish condition factor. Environmental Pollution., 126, 9-19.

Bryan, G. W., \& Langston, W. J. (1992). Bioavailability, accumulation and effects of heavy metals in sediments with special reference to United Kingdom estuaries: a review. Environmental Pollution, 76, 89-131.

Darwish, D. H. (2011). Studying of some pollutants by using chemical analysis and remote sensing for Burullus Lake, Egypt. M. Sc. Thesis, Damietta Faculty of Science, Mansoura University, Egypt.

Daviglus, M., Sheeshka, J., \& Murkin, E. (2002). Health benefits from eating fish. Comments on Toxicology, 8, 345-374.

Dural, M., Göksu, M. Z. L., \& Özak, A. A. (2007). Investigation of heavy metal levels in economically important fish species captured from the Tuzla lagoon. Food Chemistry., 102, 415-421.

El-Alfy, M. A. (2015). Comparative ecological studies on the northern Deltaic Lakes using Geographic Information System-Egypt. PhD. thesis, Faculty of Science, Mansoura University, Egypt.

El-Moselhy, K. M. (1999). Levels of some metals in fish, tilapia species caught from certain Egyptian Lakes and River Nile. Egyptian Journal of Aquatic Biology and Fisheries, 3(1), 73-83.

El-Moselhy, K. M., Saad, E. M., El-Shaarway, R. F., Mohamadein, L. I., \& Mahmoud, S. A. (2016). Assessment of heavy metals pollution using sediments and bivalve Brachidontesvariabilis as bioindicator in the Gulf of Suez, Egypt. International Journal of Marine Science, 6(26), 1-13.

EMI (2012). Egyptian Ministry of Irrigation, the amount of agricultural drainage water which entered the Lake Burullus during 2010. Organization of Mechanic and Electricity, Central Administration of the Central Delta stations, Kafr ElSheikh, Egypt.

EPA (2002): Environmental Protection Agency. National Recommended Water Quality Criteria, USA, 822-R-02-047.

Farag, M. E.-S. (2002). Genetical and physiological studies on fish collected from polluted locations. Ph. D. Thesis. Faculty of Science, Zagazig University, Egypt.

Firat, Ö., \& Kargin, F. (2010). Biochemical alterations induced by Zn and cd individually or in combination in the serum of Oreochromis niloticus. Fish Physiology and Biochemistry, 36, 647-653.

Giusti, L., Williamson, A. C., \& Mistry, A. (1999). Biologically available trace metals in Mytilusedulis from the coast of northeast England. Environment International, 25, 969-981.

Gobas, F. A. P. C., Wolf, D., Burkhard, W., Verbruggen, L. P., Plotzke, K., et al. (2009). Revisiting bioaccumulation criteria for POPs and PBT assessments. Integrated Environmental Assessment and Management, 5, 624-637.

Hamed, M. A., \& Emara, A. M. (2006). Marine molluscs as biomonitors for heavy metal levels in the Gulf of Suez, Red Sea. Journal of Marine Systems, 60, 220-234.

Harikumar, P. S., \& Jisha, T. S. (2010). Distribution pattern of trace metal pollutants in the sediments of an urban wetlands in the southwest coast of India. International Journal of Engineering, 2(5), 840-850. 
Ibrahim, N. K., \& Abu El-Regal, M. A. (2014). Heavy metals accumulation in marine edible molluscs, Timsah Lake, Suez Canal, Egypt. ARPN Journal of Science and Technology, 4(4), 282-287.

Jezierska, B., \& Witeska, M. (2006). The metal uptake and accumulation in fish living in polluted waters. Soil and Water Pollution Monitoring, Protection and Remediation, 69, 107-114.

Kennish, M. J. (1996). Practical handbook of estuarine and marine pollution. CRC Press Marine Science Series, CRC Press, Inc., Boca Raton, Florida, 524p.

Koca, Y. B., Koca, M., Yildiz, S., Gurcu, B., Osanc, E., \& Tuncbas, O. (2005). Investigation of histopathological and cytogenetic effects on Lepomis gibbosus (Pisces: Perciformes) in the Cine stream (Aydin/Turkey) with determination of water pollution. Environmental Toxicology, 20, 560-571.

Kumar, B., Mukherjee, D. P., Kumar, S., Mishra, M., Prakash, D., Singh, S. K., \& Sharma, C. S. (2011). Bioaccumulation of heavy metals in muscle tissue of fishes from selected aquaculture ponds in east Kolkata wetlands. Annals of Biological Research., 2(5), 125-134.

Masoud, M. S., El-Samra, M. I., \& El-Sadawy, M. M. (2007). Heavy-metal distribution and risk assessment of sediment and fish from El-Mex Bay, Alexandria, Egypt. Chemical Ecology, 23, 201-216.

Masoud, M. S., Fahmy, M. A., Ali, A. E., \& Mohamed, E. A. (2011). Heavy metal speciation and their accumulation in sediments of Lake Burullus, Egypt African Journal of Environmental Science and Technology, 5(4), 280-298.

Mokhtar, M. (2009). Assessment level of heavy metals in Penaeusmonodon and Oreochromis Spp. in selected aquaculture ponds of high densities development area. European Journal of Scientific Research, 30(3), 348-360.

Nagpal, N. K. (2001): Ambient water quality guidelines for manganese, overview report. National Library of Canada Cataloguing in Publication Data, ISBN 07726-4444-6, British columbia.

Ololade, I. A., Lajide, L., Amoo, I. A., \& Oladoja, N. A. (2008). Investigation of heavy metals contamination of edible marine sea food. African Journal of Pure and Applied Chemistry, 2, 121-131.

Orata, F., \& Birgen, F. (2016). Fish tissue bio-concentration and interspecies uptake of heavy metals from waste water lagoons. Journal of Pollution Effects \& Control., 4(2), 157. https://doi.org/10.4172/2375-4397.1000157.

Ozmen, M., Ayas, Z., Güngördü, A., Ekmekci, G. F., \& Yerli, S. (2008). Ecotoxicological assessment of water pollution in Sariyar Dam Lake, Turkey. Ecotoxicology and Environmental Safety, 70, 163-173.

Radwan, A. M. (2000). Discharges on the concentrations of some heavy metals in Lake Burullus. Bulletin of the National Institute of Oceanography and Fisheries, Egyptian Journal of Aquatic Research, 26, 355-364.

Radwan, A. M. (2005). The levels of heavy metals in Lake Burullus water compared with the international permissible limits. The Journal of Egyptian Academic Society for Environmental Development, 6(1), 11-26.

Radwan, A. M., \& Lotfy, I. M. (2002). On the pollution of Burullus Lake water and sediments by heavy metals. Egyptian Journal of Aquatic Biology and Fisheries, 28(4), 147-164.

Radwan, A. M., \& Shakweer, L. M. (2004). On the present status of environmental and fishery of Lake Burullus, 2.A. Distribution and concentrations of trace elements in the water and bottom sediments of Lake Burullus. The Egyptian Journal of Aquatic Research, 30(A), 43-98.

Rashed, M. N. (2001a). Cadmium and lead levels in fish (Tilapia nilotica) tissues as biological indicator for lake water pollution. Environmental Monitoring and Assessment, 68, 75-89.

Rashed, M. N. (2001b). Monitoring of environmental heavy metals in fish from Nasser Lake. Environmental International, 27, 27-33.

Saeed, S. M., \& Shaker, I. M. (2008). Assessment of heavy metals pollution in water and sediments and their effect on Oreochromisniloticusin the northern delta lakes, (pp. 475-490). Egypt: 8th International Symposium on Tilapia in Aquaculture.

Saei-Dehkordi, S. S., \& Fallah, A. A. (2011). Determination of copper, lead, cadmium and zinc content in commercially valuable fish species from the Persian Gulf using derivative potentiometric stripping analysis. Microchemical Journal, 98, 156-162.

Schuhmacher, M., \& Domingo, J. L. (1996). Concentrations of selected elements in oyster Crassostraangulata from the Spanish coast. The Bulletin of Environmental Contamination and Toxicology, 56, 106-113.

Soltan, M., Moalla, S., Rashed, M., \& Fawzy, E. (2005). Physicochemical characteristics and distribution of some metals in the ecosystem of Lake Nasser, Egypt. Toxicology and Environmental Chemistry, 87, 167-197.

Tekin-Özan, S., \& Kir, I. (2008). Seasonal variations of heavy metals in some organs of carp (Cyprinuscarpio L., 1758) from Beyşehir Lake (Turkey). Environmental Monitoring and Assessment, 138(1-3), 201-206.
Tomlinson, D. C., Wilson, D. J., Harris, C. R., \& Jeffrey, D. W. (1980). Problem in assessment of heavy metals in estuaries and the formation of pollution index. Helgol. Wiss. Meeresunlter, 33, 566-575.

UNEP (1993). Preliminary assessment of the state of pollution of the Mediterranean Sea by zinc, copper and their compounds and proposed measures, (pp. 3-7). Athens: Mediterranean Action Plan UNEP (OCA)/MED/WG.66/Inf.3 May 1993.

Usero, J., Morillo, J., \& Gracia, I. (2005). Heavy metal concentrations in molluscs from the Atlantic coast of southern Spain. Chemosphere, 59, 1175-1181.

USPHS (2005). Toxicological profile for nickel. U.S. Department of Health and Human Services, Public Health Service, Agency for Toxic Substances and Disease Registry, Atlanta, Georgia.

Watanabe, K. H., Desimone, F. W., Thiyagarajah, A., Hartley, W. R., \& Hindrichs, A. E. (2003). Fish tissue quality in the lower Mississippi River and health risks from fish consumption. Science of the Total Environment., 302, 109-126.

Yilmaz, A. B., Sangün, M. K., Yağlıoğlu, D., \& Turan, C. (2010). Metals (major, essential to non-essential) composition of the different tissues of three demersal fish species from İskenderun Bay, Turkey. Food Chemistry, 123, 410415.

Younis, A. M., Amin, H. F., Alkaladi, A., \& Mosleh, Y. Y. I. (2015). Bioaccumulation of heavy metals in fish, squids and crustaceans from the Red Sea, Jeddah Coast, Saudi Arabia. Open Journal of Marine Science, 5, 369-378.

\section{Submit your manuscript to a SpringerOpen ${ }^{\circ}$ journal and benefit from:}

- Convenient online submission

- Rigorous peer review

- Open access: articles freely available online

- High visibility within the field

Retaining the copyright to your article

Submit your next manuscript at $>$ springeropen.com 